Rev. Int. Contam. Ambie. 34 (1) 57-68, 2018

DOI: 10.20937/RICA.2018.34.01.05

\title{
SEASONAL LEVELS OF HEAVY METALS IN SOFT TISSUE AND MUSCLE OF THE PEN SHELL Atrina maura (SOWERBY, 1835) (BIVALVIA: PINNIDAE) FROM A FARM IN THE SOUTHEASTERN COAST OF THE GULF OF CALIFORNIA, MEXICO
}

\author{
Andrés Martín GÓNGORA-GÓMEZ, Ana Laura DOMÍNGUEZ-OROZCO, \\ Brenda Paulina VILLANUEVA-FONSECA, Norma Patricia MUÑOZ-SEVILLA \\ and Manuel GARCÍA-ULLOA*
}

Instituto Politécnico Nacional, Centro Interdisciplinario de Investigación para el Desarrollo Integral RegionalUnidad Sinaloa (CIIDIR-Sinaloa), Blvd. Juan de Dios Bátiz Paredes 250, Col. San Joachin, C. P. 81101, Guasave, Sinaloa, México.

* Corresponding author: turbotuag@hotmail.com

(Received August 2016; accepted May 2017)

Key words: metal concentration, seasonal variation, bivalves, culture, monitoring

\begin{abstract}
The pen shell (Atrina maura) is a filter-feeder bivalve that may accumulate metals in its body. The objective of this study was to determine seasonal concentrations of copper $(\mathrm{Cu})$, chromium $(\mathrm{Cr})$, cadmium $(\mathrm{Cd})$, nickel $(\mathrm{Ni})$, lead $(\mathrm{Pb})$, arsenic $(\mathrm{As})$, zinc $(\mathrm{Zn})$, and mercury $(\mathrm{Hg})$ in soft tissue and muscle of $A$. maura cultivated in a farm located in the southeastern coast of the Gulf of California from summer 2011 to summer 2012. Except for $\mathrm{Cu}$, the higher metal concentrations were found during the dry season (winter 2011 -spring 2012). The mean values in soft tissue fluctuated from $0.064 \pm 0.01 \mu \mathrm{g} / \mathrm{g}$ (dry weight [dw]) for $\mathrm{Hg}$ to $485.66 \pm 71.12 \mu \mathrm{g} / \mathrm{g}(\mathrm{dw})$ for $\mathrm{Zn}$, while for muscle they varied from $0.058 \pm 0.03 \mu \mathrm{g} / \mathrm{g}$ (dw) for $\mathrm{Hg}$ to $64.83 \pm 4.90 \mu \mathrm{g} / \mathrm{g}(\mathrm{dw})$ for Zn. Concentrations of cadmium $(18.15 \mu \mathrm{g} / \mathrm{g}$ in soft tissue and $1.82 \mu \mathrm{g} / \mathrm{g}$ in muscle, wet weight [ww]) and lead $(2.31 \mu \mathrm{g} / \mathrm{g}$ in soft tissue, ww) exceeded the permissible limits $(36.3,3.64$, and 2.31 times, respectively) recommended by the sanitary regulations of the official mexican standards. The results suggest that variation of metal levels in cultivated pen shell could be influenced by seasonality and anthropogenic activities such as agriculture and aquaculture developed around the culture zone. Continual monitoring of metals in farmed pen shell is recommended.
\end{abstract}

Palabras clave: concentración de metales, variación estacional, bivalvos, cultivo, monitoreo

\section{RESUMEN}

El callo de hacha (Atrina maura) es un bivalvo filtrador que puede acumular metales en su cuerpo. El objetivo de este trabajo fue determinar las concentraciones estacionales de cobre $(\mathrm{Cu})$, cromo $(\mathrm{Cr})$, cadmio $(\mathrm{Cd})$, níquel $(\mathrm{Ni})$, plomo $(\mathrm{Pb})$, arsénico (As), zinc (Zn) y mercurio (Hg) en tejido suave y músculo de $A$. maura proveniente de una granja del sureste del Golfo de California, del verano de 2011 al verano de 2012. Las concentraciones más altas de todos los metales, con excepción del $\mathrm{Cu}$, se encontraron en la estación de secas (invierno 2011-primavera 2012). Los valores promedio (peso seco) en 
el tejido suave fluctuaron de $0.064 \pm 0.01 \mu \mathrm{g} / \mathrm{g}$ para $\mathrm{Hg}$ a $485.66 \pm 71.12 \mu \mathrm{g} / \mathrm{g}$ para $\mathrm{Zn}$, mientras que en músculo variarion de $0.058 \pm 0.03 \mu \mathrm{g} / \mathrm{g}$ para $\mathrm{Hg}$ a $64.83 \pm 4.90 \mu \mathrm{g} / \mathrm{g}$ para $\mathrm{Zn}$. Las concentraciones promedio en peso húmedo para cadmio $(18.15 \mu \mathrm{g} / \mathrm{g}$ en tejido suave y $1.82 \mu \mathrm{g} / \mathrm{g}$ en músculo) y plomo $(2.31 \mu \mathrm{g} / \mathrm{g}$ en tejido suave) excedieron los límites permitidos $(36.3,3.64$ y 2.31 veces, respectivamente) por la regulación sanitaria de las Normas Oficiales Mexicanas. Los resultados sugieren que la variación de metales encontrada en el callo de hacha pudo estar influida por la estacionalidad y las actividades antropogénicas desarrolladas en los alrededores de la zona de cultivo, como agricultura y acuacultura. Se recomiendan monitoreos continuos de metales en callo de hacha cultivado.

\section{INTRODUCTION}

All soils and marine sediments contain trace metals as natural constituents that are leached into water at low concentrations (Abdel Ghani 2015). Trace metals are taken up by small organisms, entering food chains and bioaccumulating in upper trophic levels (Ruelas-Inzunza and Páez-Osuna 2008, Jara-Marini et al. 2009). Since bivalve mollusks are sedentary and benthic filter feeders (Maanan 2008), they have been used to determine the levels of contamination by metals in coastal ecosystems (Lim et al. 1995, Einollahi-Peer et al. 2010, Chaharlang et al. 2012). There are reports on the use of oysters (Le et al. 2015), mussels (Licata et al. 2004) and clams (Fang et al. 2003) as biomonitors of heavy metals in different countries. Specifically in Mexico, the oysters Crassostrea iridescens, C. corteziensis, and C. palmula, which are associated to rocky substrate and subtidal areas in coastal lagoons (Jara-Marini et al. 2009, Osuna-Martínez et al. 2011), have been used as bioindicators along the Pacific coast of Mexico (Páez-Osuna et al. 2002). It is recognized that most of the estuaries in the Gulf of California are natural areas with high productivity (Gaxiola-Castro et al. 1995, Cervantes-Duarte et al. 2005, Brusca et al. 2017), which ensures bivalve development.

The estuary of La Pitahaya is part of the San Ignacio-Navachiste-Macapule (SINM) lagoon system, and is located at the southeastern coast of the Gulf of California (Sinaloa, Mexico). It is well characterized by two-well defined periods of rainfall (dry and rainy seasons), average air temperature of $24.6{ }^{\circ} \mathrm{C}$ (mean minimum and maximum of 16 and $32{ }^{\circ} \mathrm{C}$, respectively), and pluvial precipitation ranging from 125 to $400 \mathrm{~mm}$ (Ruiz et al. 2005). The SINM lagoon is influenced by several anthropogenic activities such as intensive agriculture $(105000 \mathrm{~h})$, broiler chickens (77 785 chickens/year), shrimp aquaculture (6621 h) (Páez-Osuna and Osuna-Martínez 2015), and urban areas (city of Guasave, Sinaloa). Also, the estuary supports very important fisheries and traditionally represents a rich bivalve area, where different species are often produced (Villanueva-Fonseca 2009, Alvarez-Dagnino 2013). Thus, this area is under permanent pressure of anthropogenic pollutants originated from various sources located adjacent to the culturing areas (Osuna-Martínez et al. 2011, Páez-Osuna and Osuna-Martínez 2015).

Although some studies on metals in wild bivalve species living along the coast of Sinaloa have been reported (Páez-Osuna et al. 1991, 1993, Ayala 2004, Cadena-Cárdenas et al. 2009), the real pollution status of cultivated mollusks at the southeastern coast of the Gulf of California is not well documented. Osuna-Martínez et al. $(2010,2011)$ performed metal analysis by sampling cultured oysters seasonally from four coastal lagoons in this region (El Colorado, Santa María La Reforma, Altata and Ceuta), and BergésTiznado et al. $(2013 \mathrm{a}, \mathrm{b})$ reported the levels of arsenic and arsenic species in cultured oyster $(C$. gigas and $C$. corteziensis) from coastal lagoons in the same area, but only one work by Páez-Osuna and Osuna-Martínez (2015), who collected wild C. corteziensis and C. palmula specimens, has studied the SINM lagoon system. Among the most important bivalve species cultivated in the north coast of Sinaloa are the oysters $C$. gigas (Rodríguez-Quiroz et al. 2016) and C. corteziensis (Leal-Sepúlveda 2011), the clam Megapitaria squalida (Álvarez-Dagnino 2013), and the pen shell Atrina maura (Góngora-Gómez et al. 2011, 2016).

A. maura is an endemic bivalve of the Pacific coast of the American continent. It is naturally distributed from Baja California to Peru (Keen 1971). The adductor muscle of this mollusk is considered a seafood delicacy in many countries, which increases its market demand (Góngora-Gómez et al. 2012). Since these bivalves are commonly cultivated in the intertidal zone (Góngora-Gómez et al. 2012) where rivers and industrial drainages merge (Páez-Osuna and Osuna-Martínez 2015), they may accumulate heavy metals in their tissues proportionally to the 
degree of environmental contamination of the water (Tchounwou et al. 2012). So far, there are no previous studies on trace metal for cultivated pen shell species (Atrina and Pinna spp.) in Sinaloa.

Because of their high degree of toxicity and its significance to public health (WHO 1996), copper, chromium, cadmium, nickel, lead, arsenic, zinc and mercury constitute a high-priority metal group. On the other hand, the economic importance of $A$. maura is centered in the production of scallop but commonly local fishery communities also consume its soft tissue. Within this context, the present work was carried out in order to determine the seasonal concentrations of metals (copper $[\mathrm{Cu}]$, chromium [Cr], cadmium [Cd], nickel [Ni], lead [Pb], arsenic [As], zinc [Zn], and mercury $[\mathrm{Hg}]$ ) in soft tissue and muscle of the pen shell A. maura cultivated in the estuary of La Pitahaya (Sinaloa, Mexico), from summer 2011 to summer 2012, and to compare them with the permissible levels from national and international sanitary regulations for human consumption.

\section{MATERIALS AND METHODS}

\section{Study area}

The pen shell farm is located in the estuary of La Pitahaya, in the southeastern coast of the Gulf of California ( $\left.25^{\circ} 21^{\prime} \mathrm{N}, 108^{\circ} 38^{\prime} \mathrm{W}\right)$, Sinaloa, Mexico (Fig. 1). This estuary is located in the southernmost part of the SINM lagoon system, in the municipality of Guasave, which has a permanent connection with the Gulf of California through two mouths that create a marine environment most of the year. La Pitahaya is surrounded by mangrove communities. The climate of the study area is categorized as temperate-subhumid with summer rains (HernándezCornejo et al. 2005). Its main activity is intensive agriculture characterized by the use of irrigation and high levels of fertilizers and pesticides, whose aim is to greatly increase yield and productivity. Artisanal fishing is another important activity, and a welldeveloped industrial shrimp fishery is also relevant. Shrimp aquaculture has been strongly developed around the estuary, becoming so important over the last three decades that it is now in conflict with other activities (Ruiz-Luna and de la Lanza-Espino 1999) such as fisheries, since drainage from shrimp farms includes organic nutrients-especially during harvest-that flow into the lagoon system.

\section{Experimental animals}

Small pen shells $(\mathrm{n}=3000 ; 62.60 \pm 7.78 \mathrm{~mm}$ of shell height $[\mathrm{SH}]$ and $4.98 \pm 2.05 \mathrm{~g}$ of body weight [BW]) were obtained from the Centro de Reproducción de Especies Marinas del Estado de Sonora (Center for Reproduction of Marine Species of the State of Sonora, CREMES) located in Bahía Kino, Sonora, Mexico, and cultured according to MirandaBaeza (1994) and Almaraz-Salas (2008). The culture started in summer 2010, but pen shells were sampled for determining heavy metal levels once they reached the commercial size (SH 190-200 mm, GóngoraGómez et al. 2012) in summer 2011.

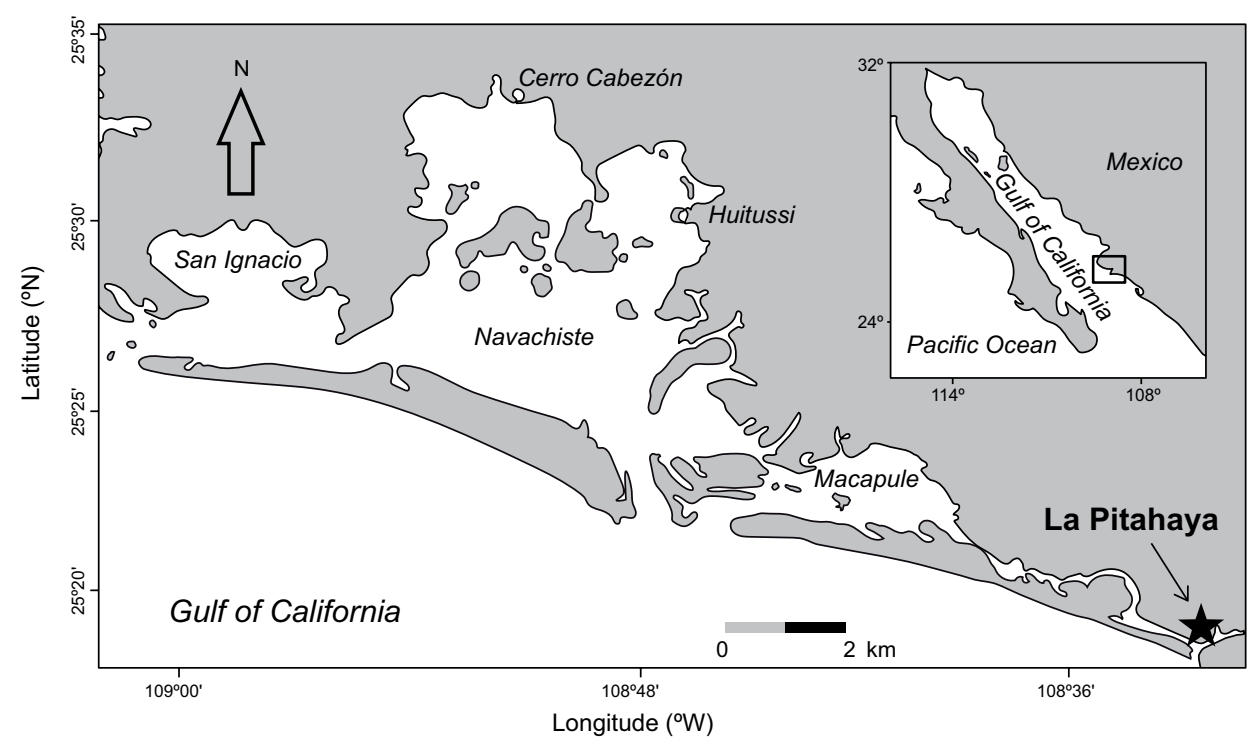

Fig. 1. Location of the pen shell culture site $(\star)$ at the estuary of La Pitahaya, Sinaloa, Mexico 


\section{Analytical procedure}

Parameters of water quality, biometrics (shell lengths and weight of bivalves), and heavy metals analysis $(\mathrm{Cu}, \mathrm{Cr}, \mathrm{Cd}, \mathrm{Ni}, \mathrm{Pb}, \mathrm{As}, \mathrm{Zn}$ and $\mathrm{Hg}$ ) of pen shells were performed at the beginning of each season from summer 2011 to summer 2012, and during the rainy season of 2011. Water temperature and dissolved oxygen were determined with an oxymeter (YSI 55/12FT, Ohio, USA), salinity was measured with a refractometer (ATAGO, S/Mill), $\mathrm{pH}$ by using a pHmeter (HANNA, HI 8314, USA) and transparency with a Secchi disk. Seasonally, SH, shell length and weight (SL and SW, respectively), and BW of 20 bivalves were measured in situ with a caliper $(0.2 \mathrm{~mm})$ and a portable balance $(0.00 \mathrm{~g})$, respectively. Then, collected pen shells were thoroughly rinsed with seawater to remove adhering algae and sediment, stored on ice in polyethylene plastic bags and transported to the laboratory (SSA 1994) for cleaning and obtaining tissue samples. All used materials were cleaned first with $\mathrm{HNO}_{3}(10 \%)$ for $24 \mathrm{~h}$ and rinsed with bidistilled water. Then, tissue samples (soft tissue and muscle) were subsequently dried by liophilization, pulverized using a mortar and pestle, and homogenized by quartering. The wet (ww) and dry (dw) weights of the samples were recorded using a digital analytical balance (AE Adam, $0.001 \mathrm{~g}$ ). To avoid metal residues, all the reagents used in this study were of high quality (GR grade, Merck Company). The samples (1.45 \pm $0.28 \mathrm{~g} \mathrm{dw}$ ) were then digested in lined digestion vessels equipped with safety relief valves, with a mixture on $\mathrm{HNO}_{3}$ and $\mathrm{H}_{2} \mathrm{O}_{2}$ using a microwave digestor (Paar Physica Multiwave Six Place). After digestion, extracts were allowed to cool at room temperature for 25 $\mathrm{min}$, and then diluted to $10 \mathrm{ml}$ with deionized water. Digests were stored in labeled polyethylene vials at $0-5^{\circ} \mathrm{C}$ until metal analysis.

Samples of $\mathrm{Cu}, \mathrm{Cr}, \mathrm{Cd}, \mathrm{Ni}, \mathrm{Pb}$ and $\mathrm{Zn}$ were analyzed by atomic absorption spectrophotometry (AAS) with flame (Perkin-Elmer, AAnalyst 100); As by AAS with hydride generation, and $\mathrm{Hg}$ by AAS with cold vapor. Standard reference material (1566b for oysters, available at the National Bureau of Standards, NBS), as well as reagent blank and duplicates were analyzed with each digestion series for quality control purposes. Experimental values for all metals (mean recovery) were in good agreement with the NBS certified values. Mean recovery percentages for $\mathrm{Cu}, \mathrm{Cr}, \mathrm{Cd}, \mathrm{Ni}, \mathrm{Pb}, \mathrm{As}, \mathrm{Zn}$ and $\mathrm{Hg}$ were 96.68, $91.19,95.60,97.30,93.80,90.00,95.75$ and $93.60 \%$, respectively. Heavy metal concentrations were calculated based on dw $(\mu \mathrm{g} / \mathrm{g})$. The detection limits of $\mathrm{Cu}, \mathrm{Cr}, \mathrm{Cd}, \mathrm{Ni}, \mathrm{Pb}, \mathrm{As}, \mathrm{Zn}$ and $\mathrm{Hg}$ were $0.032,0.032$,
$0.008,0.46,0.10,0.002,0.039$ and $0.0003 \mu \mathrm{g} / \mathrm{g}$, respectively. The levels of metals were also expressed in ww to compare them with the permissible limits from national and international regulations for human consumption, and they were calculated according to Sobrino-Figueroa et al. (2007): concentration of metal in dw/dw of sample.

\section{Data analyses}

All data were tested for normal distribution. Oneway analysis of variance (ANOVA) and Tukey's test were used as a posteriori test in biometric indexes data and among metal concentrations in soft tissues and muscle (Bhujel 2008). Concentrations of heavy metals in soft tissue were compared to concentrations collected for muscle using the t-test on each seasonal sampling. All samples were tested for $p \leq 0.05$. Correlation analysis was performed between the level of each heavy metal in soft tissue and muscle, compared to the $\mathrm{SH}$ and $\mathrm{BW}$ of $A$. maura. Statistical analyses were performed using the STATISTICA software package (StatSoft Inc., Tulsa, OK).

\section{RESULTS}

Seasonal water parameters fluctuated as follows: temperature, $18-31^{\circ} \mathrm{C}$; salinity, 26-31 PSU; dissolved oxygen, 3.9-4.1 $\mathrm{mg} / \mathrm{L}$; and $\mathrm{pH}, 7.5-7.8$. The mean depth and transparency were $1.15 \pm 0.50$ and 0.95 $\pm 0.25 \mathrm{~m}$, respectively. Water parameters and means of SL, SH, SW, and BW of A. maura from summer 2011 to summer 2012 are shown in table I. There were no significant differences $(p>0.05)$ among biometrics seasonally.

Metal concentrations in soft tissues and muscle of pen shell $(\mu \mathrm{g} / \mathrm{g}, \mathrm{dw}$ and $\mathrm{ww})$ are given in tables II and III. For soft tissue, the higher $\mathrm{Ni}, \mathrm{Pb}, \mathrm{As}, \mathrm{Zn}$ and $\mathrm{Hg}$ levels were found in winter 2011-2012. Maximum concentrations of $\mathrm{Cr}(2 \mu \mathrm{g} / \mathrm{g}, \mathrm{dw})$ and $\mathrm{Cd}(33 \mu \mathrm{g} / \mathrm{g}$, $\mathrm{dw})$ were obtained in spring 2012. Mean Cd $(18.15 \mu \mathrm{g} / \mathrm{g}$, ww $)$ and $\mathrm{Pb}(2.31 \mu \mathrm{g} / \mathrm{g}$, ww $)$ measured in soft tissue were above permissible limits $(0.5$ and $1.0 \mu \mathrm{g} / \mathrm{g}$, ww, respectively) established by the official mexican standards (SSA 1993) for Cd and Pb concentrations in fresh, refrigerated and frozen bivalve mollusks for human consumption. For muscle, the higher level for all metals was found in winter with the exception of $\mathrm{Hg}(0.073 \mu \mathrm{g} / \mathrm{g}, \mathrm{dw})$. Only the mean concentration of Cd surpassed the permissible level (1.82 $\mu \mathrm{g} / \mathrm{g}$, ww, SSA 1993).

Mean metal values for both $\mathrm{dw}$ and ww for soft tissue and muscle, decreased in the following order 
TABLE I. WATER PARAMETERS AND SEASONAL MEAN LENGTH, HEIGHT AND WIDTH (mm) OF THE SHELL, AND TOTAL WEIGHT (g) OF Atrina maura CULTURED IN THE ESTUARY OF LA PITAHAYA, SINALOA, MEXICO $(\mathrm{MEAN} \pm \mathrm{STANDARD}$ DEVIATION $)$

\begin{tabular}{|c|c|c|c|c|c|c|c|c|c|c|}
\hline & Shell length & Shell height & Shell width & Total weight & $\mathrm{T}^{\circ} \mathrm{C}$ & Sal. & DO & $\mathrm{pH}$ & Depth & Trans. \\
\hline Summer 2011 & $97.47 \pm 7.41$ & $191.80 \pm 12.72$ & $29.48 \pm 2.89$ & $163.44 \pm 27.70$ & 29 & 31 & 4.08 & 7.7 & 1.5 & 0.8 \\
\hline Rainy season 2011 & $99.33 \pm 8.98$ & $195.89 \pm 12.54$ & $32.00 \pm 2.62$ & $190.92 \pm 29.88$ & 31 & 28 & 4 & 7.7 & 1.2 & 0.9 \\
\hline Autumn 2011 & $98.63 \pm 12.76$ & $199.90 \pm 11.06$ & $32.03 \pm 2.72$ & $147.68 \pm 33.26$ & 25 & 28 & 3.9 & 7.5 & 1 & 0.7 \\
\hline Winter 2011-12 & $100.92 \pm 10.16$ & $207.60 \pm 15.85$ & $29.21 \pm 3.30$ & $202.78 \pm 49.01$ & 18 & 26 & 4 & 7.6 & 0.7 & 0.5 \\
\hline Spring 2012 & $101.36 \pm 13.21$ & $198.51 \pm 12.24$ & $31.61 \pm 4.47$ & $190.74 \pm 44.29$ & 32 & 31 & 4.09 & 7.8 & 1.8 & 1 \\
\hline Summer 2012 & $105.47 \pm 14.77$ & $193.40 \pm 7.64$ & $29.73 \pm 2.72$ & $174.30 \pm 34.73$ & 20 & 27 & 4.07 & 7.6 & 0.9 & 0.6 \\
\hline
\end{tabular}

Sal.: salinity; DO: dissolved oxygen; trans.: transparency

TABLE II. CONCENTRATION OF HEAVY METALS ( $\mu \mathrm{g} / \mathrm{g}$ DRY AND WET* WEIGHT) IN SOFT TISSUE OF CULTURED Atrina maura. PERMISSIBLE LIMITS (ww): $\mathrm{Cu}=32.5 \mu \mathrm{g} / \mathrm{g}$ (Nauen 1983); $\mathrm{Cr}=13 \mu \mathrm{g} / \mathrm{g}$ (ISSC 2007); $\mathrm{Cd}=0.5 \mu \mathrm{g} / \mathrm{g}$ (SSA 1993); $\mathrm{Ni}=80 \mu \mathrm{g} / \mathrm{g}(\mathrm{ISSC} 2007) ; \mathrm{Pb}=1 \mu \mathrm{g} / \mathrm{g}$ (SSA 1993); As = $80 \mu \mathrm{g} / \mathrm{g}$ (SSA 1993); Zn = $718 \mu \mathrm{g} / \mathrm{g}$ (FDA 1993); AND $\mathrm{Hg}=1 \mu \mathrm{g} / \mathrm{g}(\mathrm{SSA} 1993)$

\begin{tabular}{lcccccccc}
\hline & $\mathrm{Cu}$ & $\mathrm{Cr}$ & $\mathrm{Cd}$ & $\mathrm{Ni}$ & $\mathrm{Pb}$ & $\mathrm{As}$ & $\mathrm{Zn}$ & $\mathrm{Hg}$ \\
\hline Summer & $13 \pm 1.7$ & $1 \pm 0$ & $28 \pm 5$ & $6.6 \pm 1.1$ & $3 \pm 0.5$ & $1.96 \pm 0.2$ & $571 \pm 49.6$ & $0.063 \pm 0.005$ \\
2011 & $8.96^{*}$ & $0.68^{*}$ & $19.31^{*}$ & $4.55^{*}$ & $2.06^{*}$ & $1.35^{*}$ & $393.79^{*}$ & $0.043^{*}$ \\
\hline Rainy & $11.6 \pm 0.5$ & $1 \pm 0$ & $23 \pm 2.3$ & $8 \pm 1$ & $2.3 \pm 0.5$ & $0.28 \pm 0.01$ & $357 \pm 41$ & $0.056 \pm 0.005$ \\
season 2011 & $8.0^{*}$ & $0.68^{*}$ & $15.68^{*}$ & $5.51^{*}$ & $1.58^{*}$ & $0.19^{*}$ & $246.20^{*}$ & $0.038^{*}$ \\
\hline Autumn & $13 \pm 2$ & $1 \pm 0$ & $21 \pm 5.2$ & $9.3 \pm 1.5$ & $2.6 \pm 0.5$ & $2.5 \pm 0.1$ & $309 \pm 53$ & $0.07 \pm 0$ \\
2011 & $8.96^{*}$ & $0.68^{*}$ & $14.48^{*}$ & $6.41^{*}$ & $1.79^{*}$ & $1.72^{*}$ & $213.10^{*}$ & $0.048^{*}$ \\
\hline Winter & $9.6 \pm 0.5$ & $1.6 \pm 0.5$ & $25 \pm 2.3$ & $15 \pm 1$ & $4.6 \pm 0.5$ & $4.6 \pm 0.5$ & $598 \pm 121$ & $0.076 \pm 0.005$ \\
$2011-12$ & $6.62^{*}$ & $1.10^{*}$ & $17.24^{*}$ & $10.34^{*}$ & $3.17^{*}$ & $3.17^{*}$ & $412.41^{*}$ & $0.052^{*}$ \\
\hline Spring & $11.6 \pm 1.1$ & $2 \pm 0$ & $33 \pm 4.6$ & $13.3 \pm 1.1$ & $4.6 \pm 0.5$ & $4.5 \pm 0.5$ & $508 \pm 138$ & $0.06 \pm 0$ \\
2012 & $8.0^{*}$ & $1.37^{*}$ & $22.75^{*}$ & $9.17^{*}$ & $3.17^{*}$ & $3.10^{*}$ & $350.34^{*}$ & $0.041^{*}$ \\
\hline Summer & $13 \pm 2$ & $1 \pm 0$ & $28 \pm 6.5$ & $7 \pm 1.15$ & $3 \pm 0$ & $1.9 \pm 0.37$ & $571 \pm 22.8$ & $0.06 \pm 0.005$ \\
2012 & $8.96^{*}$ & $0.68^{*}$ & $19.31^{*}$ & $4.82^{*}$ & $2.06^{*}$ & $1.31^{*}$ & $393.79^{*}$ & $0.041^{*}$ \\
\hline Average & 11.96 & 1.26 & 26.33 & 9.86 & 3.35 & 2.62 & 485.66 & 0.064 \\
& $8.24^{*}$ & $0.86^{*}$ & $18.15^{*}$ & $6.8^{*}$ & $2.31^{*}$ & $1.80^{*}$ & $334.93^{*}$ & $0.044^{*}$ \\
\hline
\end{tabular}

$\mathrm{Zn}>\mathrm{Cd}>\mathrm{Cu}>\mathrm{Ni}>\mathrm{Pb}>\mathrm{As}>\mathrm{Cr}>\mathrm{Hg}$, and $\mathrm{Zn}>$ $\mathrm{Cd}>\mathrm{Ni}>\mathrm{Pb}>\mathrm{Cu}>\mathrm{Cr}>\mathrm{As}>\mathrm{Hg}$, respectively. The ANOVA results for each tissue separately showed differences $(p<0.05)$ among all heavy metal concentrations (degree of freedom [df] $=7,40, \mathrm{~F}=90.77$, $\mathrm{p}=0.0001$ for soft tissue, and $\mathrm{df}=7,40, \mathrm{~F}=60.54$, $\mathrm{p}=0.0001$ for muscle). Zn showed the highest mean levels (485.66 and $64.83 \mu \mathrm{g} / \mathrm{g}$, dw, in soft tissue and muscle, respectively). Mean concentrations (dw) in soft tissue $(0.064 \mu \mathrm{g} / \mathrm{g})$ and muscle $(0.058 \mu \mathrm{g} / \mathrm{g})$ were only similar for $\mathrm{Hg}(\mathrm{df}=5, \mathrm{t}=0.93, \mathrm{p}=0.37)$.

Correlation analyses between metal concentrations and pen shell biometrics are depicted in table IV. For soft tissue, there were significant correlations between $\mathrm{SH}$ and $\mathrm{Hg}$ concentration $(\mathrm{r}=0.85, \mathrm{p}=0.03)$, and between $\mathrm{BW}$ and $\mathrm{Cu}$ concentration $(\mathrm{r}=-0.85$, $\mathrm{p}=0.028$ ). In the case of muscle, $\mathrm{Cd}$, Ni and $\mathrm{Cu}$ concentrations showed significant correlations with $\mathrm{SH}$ $(\mathrm{r}=0.85, \mathrm{p}=0.03 ; \mathrm{r}=0.94, \mathrm{p}=0.005$, and $\mathrm{r}=0.87$, $\mathrm{p}=0.02$, respectively).

\section{DISCUSSION}

Since pen shell is a popular raw dietary item in the Gulf of California, it is important to determine the concentrations of heavy metals to assess whether these levels may constitute a health hazard for consumers. Although the economic importance of pen shell culturing in La Pitahaya, Sinaloa is derived 
TABLE III. CONCENTRATION OF HEAVY METALS ( $\mu \mathrm{g} / \mathrm{g}$ DRY AND WET* WEIGHT) IN MUSCLE OF CULTURED Atrina maura. PERMISSIBLE LIMITS (ww): $\mathrm{Cu}=32.5 \mu \mathrm{g} / \mathrm{g}$ (Nauen 1983); $\mathrm{Cr}=13 \mu \mathrm{g} / \mathrm{g}$ (ISSC 2007); $\mathrm{Cd}=0.5 \mu \mathrm{g} / \mathrm{g}($ SSA 1993); $\mathrm{Ni}=80 \mu \mathrm{g} / \mathrm{g}($ ISSC 2007); $\mathrm{Pb}=1 \mu \mathrm{g} / \mathrm{g}($ SSA 1993); As $=80 \mu \mathrm{g} / \mathrm{g}(\mathrm{SSA} 1993) ;$ $\mathrm{Zn}=718 \mu \mathrm{g} / \mathrm{g}(\mathrm{FDA} 1993) ; \mathrm{AND} \mathrm{Hg}=1 \mu \mathrm{g} / \mathrm{g}(\mathrm{SSA} 1993)$

\begin{tabular}{lcccccccc}
\hline & $\mathrm{Cu}$ & $\mathrm{Cr}$ & $\mathrm{Cd}$ & $\mathrm{Ni}$ & $\mathrm{Pb}$ & $\mathrm{As}$ & $\mathrm{Zn}$ & $\mathrm{Hg}$ \\
\hline Summer & $1 \pm 0$ & $0.4 \pm 0$ & $2 \pm 1$ & $1 \pm 0$ & $0.66 \pm 0$ & $0.51 \pm 0.03$ & $53 \pm 7$ & $0.05 \pm 0.003$ \\
2011 & $0.68^{*}$ & $0.27^{*}$ & $1.37^{*}$ & $0.68^{*}$ & $0.45^{*}$ & $0.35^{*}$ & $36.55^{*}$ & $0.03^{*}$ \\
\hline Rainy season & $1 \pm 0$ & $0.4 \pm 0$ & $1 \pm 0$ & $1 \pm 0$ & $\mathrm{ND}$ & $0.20 \pm 0.08$ & $43 \pm 1.5$ & $0.06 \pm 0.005$ \\
2011 & $0.68^{*}$ & $0.27^{*}$ & $0.68^{*}$ & $0.68^{*}$ & & $0.0 .13^{*}$ & $29.65^{*}$ & $0.04^{*}$ \\
\hline Autumn & $1 \pm 0$ & $0.63 \pm 0.32$ & $3 \pm 2$ & $1.3 \pm 0.5$ & $\mathrm{ND}$ & $0.51 \pm 0.17$ & $57 \pm 6$ & $0.08 \pm 0$ \\
2011 & $0.68^{*}$ & $0.43^{*}$ & $2.06^{*}$ & $0.89^{*}$ & & $0.35^{*}$ & $39.31^{*}$ & $0.05^{*}$ \\
\hline Winter & $1.66 \pm 0.5$ & $1 \pm 0$ & $5.6 \pm 3$ & $2.3 \pm 1.5$ & $2 \pm 0$ & $0.57 \pm 0.13$ & $105 \pm 6$ & $0.073 \pm 0.005$ \\
$2011-12$ & $1.14^{*}$ & $0.68^{*}$ & $3.86^{*}$ & $1.58^{*}$ & $1.37^{*}$ & $0.39^{*}$ & $72.41^{*}$ & $0.05^{*}$ \\
\hline Spring & $1 \pm 0$ & $1 \pm 0$ & $3.3 \pm 0.5$ & $1.3 \pm 0.5$ & $2 \pm 0$ & $0.31 \pm 0.06$ & $66 \pm 2$ & $0.05 \pm 0.003$ \\
2012 & $0.68^{*}$ & $0.68^{*}$ & $2.27^{*}$ & $0.89^{*}$ & $1.37^{*}$ & $0.21^{*}$ & $45.51^{*}$ & $0.03^{*}$ \\
\hline Summer & $1 \pm 0$ & $0.5 \pm 0$ & $1 \pm 0$ & $0.33 \pm 0$ & $1.3 \pm 0.5$ & $0.2 \pm 0.01$ & $65 \pm 6$ & $0.04 \pm 0.001$ \\
2012 & $0.68^{*}$ & $0.34^{*}$ & $0.68^{*}$ & $0.22^{*}$ & $0.89^{*}$ & $0.13^{*}$ & $44.82^{*}$ & $0.02^{*}$ \\
\hline Average & 1.11 & 0.655 & 2.65 & 1.205 & 0.993 & 0.383 & 64.83 & 0.058 \\
& $0.76^{*}$ & $0.45^{*}$ & $1.82^{*}$ & $0.83^{*}$ & $0.68^{*}$ & $0.26^{*}$ & $44.71^{*}$ & $0.04^{*}$ \\
\hline
\end{tabular}

ND: not detected

from the muscle production (known as "callo"), local fishery communities consume the soft tissue of this bivalve, therefore the knowledge of metal levels in both soft tissue and muscle of cultured $A$. maura is an important priority for this study. In comparison with the permissible limits (given in ww) set for $\mathrm{Cu}$ (32.5 $\mu \mathrm{g} / \mathrm{g}$, Nauen 1983), Cr (13 $\mu \mathrm{g} / \mathrm{g}$, ISSC 2007), Ni $(80 \mu \mathrm{g} / \mathrm{g}$, ISSC 2007), As (80 $\mu \mathrm{g} / \mathrm{g}$, SSA 1993), $\mathrm{Zn}(718 \mu \mathrm{g} / \mathrm{g}$, FDA 1993) and $\mathrm{Hg}(1 \mu \mathrm{g} / \mathrm{g}$, SSA 1993), all the mean values in soft tissue and muscle of $A$. maura were lower than the limits established by Mexican and international regulations, with the exception of $\mathrm{Cd}(0.5 \mu \mathrm{g} / \mathrm{g})$ and $\mathrm{Pb}(1 \mu \mathrm{g} / \mathrm{g})$, which were found to be higher than the permissible limits for fresh mollusks (SSA 1993).

Due to the commercial importance of bivalves in the region studied, surveys on trace metal levels in different species have been carried out for decades (Páez-Osuna et al. 1991). Cd mean values obtained in soft tissue $(28 \mu \mathrm{g} / \mathrm{g}, \mathrm{dw})$ and muscle $(2.65 \mu \mathrm{g} / \mathrm{g}, \mathrm{dw})$ of pen shell were higher than those reported by Ayala (2004) for the oyster C. corteziensis $(0.16 \mu \mathrm{g} / \mathrm{g}, \mathrm{dw})$ and the mussel Mytella strigata $(0.30 \mu \mathrm{g} / \mathrm{g}, \mathrm{dw})$ sampled in La Pitahaya in 2002. In another study conducted during 2011 in $C$. gigas cultured in the same estuary, the mean value obtained by Castro-Sánchez (2013) was of $14.50 \mu \mathrm{g} / \mathrm{g}(\mathrm{dw})$ for Cd. In the same study, the mean levels of $\mathrm{Pb}$ for soft tissue $(3.0 \mu \mathrm{g} / \mathrm{g}, \mathrm{dw})$ and muscle $(0.99 \mu \mathrm{g} / \mathrm{g}, \mathrm{dw})$ of $A$. maura were also higher than those reported by Ayala (2004) for $C$. corteziensis $(0.28 \mu \mathrm{g} / \mathrm{g}, \mathrm{dw})$ and $\mathrm{M}$. strigata $(0.30$ $\mu \mathrm{g} / \mathrm{g}, \mathrm{dw})$, but comparablewith the levels registered by Castro-Sánchez (2013) for C. gigas in the same estuary $(2.06 \mu \mathrm{g} / \mathrm{g}, \mathrm{dw})$. In this work most metals were generally found in the soft tissue rather than in muscle of $A$. maura. $\mathrm{Pb}$ was not detected in muscle during both the autumn and the rainy season of 2011, probably due to metal dilution (Osuna-Martínez et al. 2010). Since the mean ww levels of Cd in muscle exceeded the permissible values it is assumed that in both tissues this metal could represent a potential risk if consumed. However, more studies are recommended regarding the different chemical forms of the metals that surpassed the permissible limits to better understand their toxicity. Cobbett and Goldsbrough (2002) stated that neutralization of some metals is potentially achieved when they are associated to proteins, and may be eliminated from an organism by different metabolic routes (Sandrin and Maier 2002, Flora et al. 2012).

Ingestion of $\mathrm{Cd}$ is associated to human skeletal damage and reproductive deficiencies, and foodstuffs are the main sources of this metal (Kyprianou 2005). Jović et al. (2011) mentioned that the presence of high levels of $\mathrm{Cd}$ is often associated with human 
TABLE IV. CORRELATION VALUES BETWEEN METAL CONCENTRATIONS AND SHELL'S HEIGHT AND TOTAL WEIGHT, IN SOFT TISSUES AND MUSCLE OF CULTURED Atrina maura

\begin{tabular}{|c|c|c|c|c|c|c|c|c|}
\hline \multicolumn{9}{|c|}{ SOFT TISSUE } \\
\hline Shell height & $\mathrm{Cu}$ & $\mathrm{Cd}$ & $\mathrm{Cr}$ & $\mathrm{Ni}$ & $\mathrm{Pb}$ & As & $\mathrm{Zn}$ & $\mathrm{Hg}$ \\
\hline A & 236.23 & 214.56 & 192.75 & 185.44 & 189.4 & 192.64 & 197.07 & 154.22 \\
\hline $\mathrm{b}$ & -3.27 & -0.66 & 3.43 & 1.18 & 2.29 & 1.69 & $4.3^{-5}$ & 668.20 \\
\hline $\mathrm{F}$ & 5.26 & 1.23 & 0.27 & 3.94 & 0.74 & 1.23 & 0.00 & 10.44 \\
\hline $\mathrm{p}$ & 0.08 & 0.32 & 0.62 & 0.11 & 0.43 & 0.33 & 0.99 & $0.03 *$ \\
\hline \multicolumn{9}{|l|}{ Total weight } \\
\hline $\mathrm{a}$ & 334.27 & 137.91 & 141.51 & 142.27 & 136.74 & 167.23 & 144.81 & 180.58 \\
\hline $\mathrm{b}$ & -13.03 & 1.53 & 29.04 & 3.65 & 12.40 & 4.22 & 0.06 & -35.50 \\
\hline $\mathrm{F}$ & 11.28 & 0.46 & 2.42 & 2.54 & 2.36 & 0.54 & 0.83 & 0.00 \\
\hline $\mathrm{p}$ & $0.028^{*}$ & 0.53 & 0.19 & 0.18 & 0.19 & 0.50 & 0.41 & 0.98 \\
\hline \multicolumn{9}{|c|}{ MUSCLE } \\
\hline \multicolumn{9}{|l|}{ Shell height } \\
\hline $\mathrm{a}$ & 173.99 & 187.12 & 189.30 & 181.45 & 196.30 & 187.97 & 183.87 & 180.86 \\
\hline $\mathrm{b}$ & 21.00 & 3.54 & 10.32 & 11.44 & 0.71 & 24.88 & 0.19 & 283.96 \\
\hline $\mathrm{F}$ & 13.71 & 10.44 & 1.27 & 30.44 & 0.05 & 2.44 & 3.80 & 8.13 \\
\hline $\mathrm{p}$ & $0.02 *$ & $0.03 *$ & 0.32 & $0.005 *$ & 0.83 & 0.19 & 0.12 & $0.04 *$ \\
\hline \multicolumn{9}{|l|}{ Total weight } \\
\hline $\mathrm{a}$ & 124.47 & 154.99 & 134.85 & 142.60 & 165.25 & 185.77 & 148.20 & 179.96 \\
\hline $\mathrm{b}$ & 48.94 & 8.27 & 57.55 & 26.12 & 11.81 & -18.35 & 0.45 & -28.99 \\
\hline $\mathrm{F}$ & 2.10 & 1.91 & 6.35 & 2.42 & 1.53 & 0.07 & 1.04 & 0.00 \\
\hline $\mathrm{p}$ & 0.22 & 0.23 & 0.06 & 0.19 & 0.28 & 0.80 & 0.36 & 0.96 \\
\hline
\end{tabular}

a: intercept; b: slope, F: Fisher's value

* Significant correlation, $\mathrm{p}<0.05$

activity, being industrial fertilizers and sewage sludge the main $\mathrm{Cd}$ inputs. The same conclusions were given by Pérez et al. (2005), who reported high $\mathrm{Cd}$ concentrations in the mussel M. edulis collected near sites with industrial activity in Argentina. The higher mean $\mathrm{Cd}$ concentrations found during the dry season (winter-spring) could also be explained by the presence of upwelling during this season, since the Gulf of California is characterized by upwelling events along its eastern coast (Staines-Urías et al. 2009). A similar increase of Cd levels during the dry season in cultured oysters was observed by Osuna-Martínez et al. (2011). Besides, the high Cd concentrations found in the Gulf of California have been attributed to the presence of natural phosphorite deposits (Méndez et al. 2006). $\mathrm{Pb}$ is known as a metabolic poison that can be in humans (Stankovic et al. 2012); its absorption induces poor development in children, while adults are affected by cardiovascular and pressure diseases (Kyprianou 2005). Intense transportation and fishing boat activities, as well as mining (Cadena-Cárdenas et al. 2009), aquaculture and agriculture (Páez-Osuna et al. 2003) could be the most important $\mathrm{Pb}$ sources in this region. Amiard et al. (1986) mention that low $\mathrm{Pb}$ concentrations are often observed in shellfish due to the low bioavailability to marine animals of both dissolved and dietary lead, but it seems that there is a high presence of toxic $\mathrm{Pb}$ from anthropogenic sources in La Pitahaya's environment, therefore its availability to pen shell increases. Soto-Jiménez and Flegal (2009) mention that the major transport routes of $\mathrm{Pb}$ in the Gulf of California are the runoff from urban settlements into nearby watersheds, where it is transported by combined sewage systems, agriculture effluents, rural runoff, and direct atmospheric deposition. The same conclusion was given by Páez-Osuna and Osuna-Martínez (2015), who analyzed the $\mathrm{Pb}$ concentration in two mangrove oyster species from seven coastal lagoons in Sinaloa.

The varied metal levels in mollusks from the abovementioned studies suggest that concentrations may depend on human activities in the region 
(Jakimska et al. 2011), among other factors. Specifically, the main sources of contamination for La Pitahaya are the municipal sewage of Guasave, agricultural drainage that transports fertilizers and biocides, and drainage from shrimp farms, which includes organic nutrients, especially during the harvest, that flow into this estuary (Ruiz-Luna and de la Lanza-Espino 1999). The Guasave region is considered as the "agricultural heart of Mexico" for its large agricultural production of items such as corn, bean and tomato, in more than 220000 ha. Consequently, fertilizers and fungicides containing $\mathrm{Cu}, \mathrm{Cd}, \mathrm{Ni}$ and $\mathrm{Zn}$ are commonly applied in the region (Páez-Osuna et al. 1993). Agrochemicals are eventually leached from the soil and transported to the coastal zones (Páez-Osuna and Osuna-Martínez 2015), where the pen shell farm was located.

Environmental parameters such as seasonality directly influence metal concentrations in animals. Coinciding with the reports of Lim et al. (1995), PáezOsuna et al. (1995), Chen and Chen (2003) and Le et al. (2015) for different mollusk species, the lower metal levels in A. maura were found during and after the rainy season. Concentrations tend to increase during the dry season due to sedimentation of metals from the water column to the bottom (Palomares-García et al. 2009), where pen shells are greatly exposed to those particles. A constant seasonal pattern is not observed in $\mathrm{Cu}$ levels possibly due to the combined effect of variations in the rate of influx from agriculture practices in the region and the $\mathrm{Cu}$ metabolism. $\mathrm{Cu}$ is an essential metal in the production of haemocyanin, which serves as respiratory pigment for bivalves (Morse et al. 1986, Taylor and Anstiss 1999). Bjerregaard and Depledge (1994) concluded that Cd uptake and bioaccumulation in crustaceans and mollusks is higher at low salinities during the rainy season. The levels of studied metals showed intermittent values among samplings, which suggests the depuration or removal of metals by different mechanisms: through the body surface or gills, and excreting it into the gut or with urine (Bryan 1971). Some metals are stored in shell surfaces since the shell layer (periostracum) is in direct contact with the environment (Yap et al. 2003). Shells sequestrate part of the heavy metals uptake as a sort of detoxification process of non-essential and excessive essential metals that takes place in mollusks (Cravo et al. 2004). Also, trace metals can be transferred from gonadal tissue to the eggs during gametogenesis (Greig et al. 1975) and be lost at spawning (Páez-Osuna et al. 1995). According to Góngora-Gómez et al. (2012), A. maura can complete its reproductive cycle in 12-15 months, thus heavy metals could be lost in the reproductive process.
Nevertheless, studies on the relationship between the reproduction cycle and metal levels are needed to better understand such detoxification process. On other hand, it seems that La Pitahaya has an efficient depuration system of metals due to its higher exchange rate with open-sea water (Hernández-Cornejo et al. 2005).

Despite the small range between maximum and minimum values of shell height $(15 \mathrm{~mm}), \mathrm{Hg}$ concentrations in soft tissue, and $\mathrm{Cd}, \mathrm{Ni}$ and $\mathrm{Cu}$ concentrations in muscle of $A$. maura increased with shell height, which suggests that these concentrations could be proportional to the pen shell size. Bryan (1971) and Yap et al. (2009) stated that age/size are important factors in determining the concentration of metals in organisms. However, it is highly recommended to monitor metal levels in pen shell tissues from the beginning of the culture period to better understand the relationship between pen shell size and metal levels.

\section{CONCLUSIONS}

The overall results obtained indicate a considerable availability of the studied metals for A. maura. Different levels of these metals were found in soft tissue and muscle, mainly according with seasonality and anthropogenic activities in the region. Therefore, regular monitoring is needed, especially in the case of risky trace elements like $\mathrm{Cd}$ and $\mathrm{Pb}$. It is also recommended to yearly monitor metal concentrations in water, soil, and the shell and edible parts of the species harvested or cultured in the region, as well as carrying out more studies related to the different chemical forms of those metals that surpassed the permissible limits, to better understand their toxicity. Our data could allow consumers to be informed about possible risks of contamination.

\section{ACKNOWLEDGMENTS}

The authors thank the Instituto Politécnico Nacional for funding and logistic support (SIP-20113719 and SIP-20120471), and Sabyel Armenta Rivera for his technical assistance.

\section{REFERENCES}

Abdel Ghani S.A. (2015). Trace metals in seawater, sediments and some fish species from Marsa Matruh 
Beaches in north-western Mediterranean coast, Egypt. Egyptian J. of Aqua. Res. 41 (2), 145-154.

DOI: 10.1016/j.ejar.2015.02.006

Almaraz-Salas J.C. (2008). Primer cultivo experimental de callo de hacha Atrina maura (Sowerby 1835) en la ensenada La Palmita, Navolato, Sinaloa. B.Sc. thesis. Universidad de Occidente, Guasave, Sinaloa, Mexico, $74 \mathrm{pp}$.

Álvarez-Dagnino E. (2013). Variación proteica y morfológica en tres poblaciones de almeja chocolate Megapitaria squalida (Sowerby 1835) en las costas de Sinaloa. B.Sc. thesis. Universidad de Occidente, Guasave, Sinaloa, Mexico, 83 pp.

Amiard J.C., Aimard-Triquet C., Berthet B. and Netayer C. (1986). Contribution to the ecotoxicology study of cadmium, lead, copper and zinc in the mussel Mytilus edulis: I. Field study. Mar. Biol. 90 (3), 425-431.

DOI: 10.1007/BF00428566

Ayala B.L. (2004). Distribución de la concentración de metales pesados en sedimento y su relación con organismos indicadores (Crassostrea sp. y Mytella sp.) en el Sistema Lagunar de Guasave, Sinaloa. M.Sc. thesis. Instituto Politécnico Nacional, Centro Interdisciplinario de Investigación para el Desarrollo Integral Regional, Unidad Sinaloa, Guasave, Sinaloa, Mexico, 106 pp.

Bergés-Tiznado M.E., Páez-Osuna F., Notti A. and Regoli F. (2013a). Biomonitoring of arsenic through mangrove oyster (Crassostrea corteziensis Hertlien, 1951) from coastal lagoons (SE Gulf of California): occurrence of arsenobetaine and other arseno-compounds. Environ. Monit. Assess. 185 (9), 7459.

DOI: $10.1007 / \mathrm{s} 10661-013-3112-8$

Bergés-Tiznado M.E., Páez-Osuna F., Notti A. and Regoli F. (2013b). Arsenic and arsenic species in cultured oyster (Crassostrea gigas and C. corteziensis) from coastal lagoons of the SE Gulf of California, Mexico. Biol. Trace Element Res. 151 (1), 43-49.

DOI: $10.1007 / \mathrm{s} 12011-012-9536-0$

Bhujel R.C. (2008). Statistics for aquaculture. WileyBlackwell, Ames, Iowa, USA, 222 pp.

Bjerregaard P. and Depledge A. (1994). Cadmium accumulation in Littorina littorea, Mytilus edulis and Carcinus maenas. Mar. Biol. 119 (3), 385-395.

DOI: $10.1007 / \mathrm{BF} 00347535$

Brusca R.C., Álvarez-Borrego S., Hastings P.A. and Findley L.T. (2017) Colorado river flow and biological productivity in the Northern Gulf of California, Mexico. Earth-Sci. Rivers 164, 1-30. DOI: 10.1016/j.earscirev.2016.10.012

Bryan G.W. (1971). The effects of heavy metals (other than mercury) on marine and estuarine organisms. Proc. Roy. Soc. London. B 177 (1048), 389-410.

DOI: $10.1098 /$ rspb.1971.0037
Cadena-Cárdenas L., Méndez-Rodríguez L., ZentenoSavín T., García-Hernández J. and Acosta-Vargas B. (2009). Heavy metal levels in marine mollusks from areas with, or without, mining activities along the Gulf of California, Mexico. Arch. Environ. Cont. Toxicol. 57 (1), 96-102. DOI: 10.1007/s00244-008-9236-0

Castro-Sánchez J.M. (2013). Concentración de metales pesados: $\mathrm{Cu}, \mathrm{Cd}, \mathrm{Cr}, \mathrm{Ni}, \mathrm{Pb}, \mathrm{Zn}, \mathrm{As}$, y Hg en un cultivo de ostión japonés. B.Sc. thesis. Universidad de Occidente, Guasave, Sinaloa, Mexico, 79 pp.

Cervantes-Duarte R., Verdugo-Díaz G. and ValdezHolguín J.E. (2005). Modelo estacional de producción primaria estimada mediante fluorescencia natural en una región costera del Golfo de California, México. Hidrobiológica 15 (1), 79-87.

Chaharlang B.H., Bakhtiari A.R. and Yavari V. (2012). Assessment of cadmium, copper, lead and zinc contamination using oysters (Saccostrea cucullata) as biomonitors on the coast of the Persian Gulf, Iran. Bull. Environ. Cont. Toxicol. 88 (6), 956-961. DOI: $10.1007 / \mathrm{s} 00128-012-0591-1$

Chen Ch.-Y. and Chen M.-H. (2003). Investigation of Zn, $\mathrm{Cu}, \mathrm{Cd}$ and $\mathrm{Hg}$ concentrations in the oyster of Chi-ku, Tai-shi and Taping Bay, Southwestern Taiwan. J. Food Drug Anal. 11 (1), 32-38.

Cobbett C. and Goldsbrough P. (2002). Phytochelatins and metallothioneins: roles in heavy metal detoxification and homeostasis. Annual Rev. Plant Biol. 53 (1), 159182. DOI: 10.1146/annurev.arplant.53.100301.135154

Cravo A., Foster P. and Bebianno M.J. (2004). Minor and trace elements in the shell of Patella aspera. Environ. Inter. 28 (4), 295-302. DOI: $10.1016 / \mathrm{S} 0160-4120(02) 00038-7$

Einollahi-Peer F., Safahieh A., Dadollahi-Sohrab A. and Pakzad-Tochaii S. (2010). Heavy metal concentrations in rock oyster Socosstrea cucullata from Iranian coasts of the Oman Sea. Trakia J. Sci. 8 (1), 79-86.

Fang Z.I., Cheung R.Y. and Wong M.H. (2003). Heavy metals in oysters, mussels and clams collected from coastal sites along the Pearl River Delta, South China. J. Environ. Sci. (China) 15 (1), 9-24.

FDA (1993). Guidance document for lead in shellfish. Center for Food Safety and Applied Nutrition. United States Food and Drug Administration, Washington, D. C.

Flora G., Gupta D. and Tiwari A. (2012). Toxicity of lead: a review with recent updates. Interdiscip. Toxicol. 5 (2), 47-58. DOI: 10.2478/v10102-012-0009-2

Gaxiola-Castro G., García-Córdova J., Valdez-Holguín J.R. and Botello-Ruvalcaba M. (1995). Spatial distribution of chlorophyll a and the primary productivity in relation to winter physical structure in the Gulf of California. Cont. Shelf Res. 15 (9), 1043-1059. DOI: 0278-4343(94)00071-9 
Góngora-Gómez A.M., García-Ulloa M., DomínguezOrozco A.L. and Hernández-Sepúlveda J.A. (2011). Crecimiento del callo de hacha Atrina maura (Sowerby, 1835) (Bivalvia: Pinnidae) cultivado a diferentes densidades. Avan. Inves. Agropec. 15 (2), 79-94.

Góngora-Gómez A.M., García-Ulloa M., DomínguezOrozco A.L., Hernández-Sepúlveda J.A. and NolascoOrta A. (2012). Desarrollo científico y biotecnológico para el cultivo comercial del callo de hacha (Atrina maura) en el estado de Sinaloa, México. Mundilibros, Tlaxcala, Mexico, 118 pp.

Góngora-Gómez A.M., García-Ulloa M., HernándezSepúlveda J.A., Domínguez-Orozco A.L. and SainzHernández J.C. (2016). Crecimiento y supervivencia del callo de hacha Atrina maura (Bivalvia: Pinnidae) cultivado en la costa sureste del Golfo de California, México. Rev. Biol. Mar. Oceanog. 51 (3), 665-673. DOI: $10.4067 / \mathrm{S} 0718-19572016000300017$

Greig R.A., Nelson B.A. and Nelson D.A. (1975). Trace metal content in the American oyster. Mar. Poll. Bull. $6(5), 72-73$.

DOI: $10.1016 / 0025-326 X(75) 90100-9$

Hernández-Cornejo R., Koedam N., Ruiz-Luna A., Troell M. and Dahdouh-Guebas F. (2005). Remote sensing and ethnobotanical assessment of the mangrove forest changes in the Navachiste-San IgnacioMacapule lagoon complex, Sinaloa, Mexico. Ecol. Soc. 10 (1), 16.

ISSC (2007). National shellfish sanitation program. Guide for the control of molluscan shellfish. Interstate Shellfish Sanitation Conference. U.S. Food and Drug Administration, Department of Health and Human Services. Washington, D.C., 549 pp.

Jakimska A., Konieczka P., Skora K. and Namiesnik J. (2011). Bioaccumulation of metals in tissues of marine animals. Part II: Metal concentrations in animal tissues. Pol. J. Environ. Stud. 20 (5), 1127-1146.

Jara-Marini M.E., Soto-Jiménez M.F. and Páez-Osuna F. (2009). Trophic relationships and transference of cadmium, copper, lead, and zinc in a subtropical coastal lagoon food web from SE Gulf of California. Chemosphere 77 (10), 1366-1373. DOI: 10.1016/j. chemosphere.2009.09.025

Jović M., Stanković A., Slavković-Beskoski L., Tomić I. and Degetto S. (2011). Mussels as a bio-indicator of the environmental quality of the coastal water of the Boka Kotorska Bay (Montenegro). J. Serbian Chem. Soc. 76 (6), 933-946. DOI: 10.2298/JSC101007075J

Keen A.M. (1971). Sea shells of tropical West America. Marine mollusks from Baja California to Peru. Stanford University Press, California, 1074 pp.

Kyprianou M. (2005). Commission regulation (EC) No. 466/2001 of 8 March 2001. Official Journal of European Communities. 1.77/1. [online] www. eur-lex.europa.eu/legal-content/EN/TXT/?uri= CELEX\%3A32001R0044 03/05/2017.

Le Q.D., Bach L.G. and Aria T. (2015). Monitoring heavy metal contamination using rocky oyster (Saccostrea glomerata) in Haiphong-Halong Coastal area, North Vietnam. Int. J. Environ. Res. 9 (2), 1373-1378.

Leal-Sepúlveda A.L. (2011). Efecto de la estación y la densidad de siembra en el crecimiento e índice de condición fisiológica del ostión de placer Crassostrea corteziensis cultivado en Guasave, Sinaloa. M.Sc. thesis. Instituto Politécnico Nacional, Centro Interdisciplinario de Investigación para el Desarrollo Integral Regional, Unidad Sinaloa, Guasave, Sinaloa, Mexico, $92 \mathrm{pp}$.

Licata P., Trombetta D., Christiani M., Martino D. and Naccari F. (2004). Organochlorine compounds and heavy metals in the soft tissue of the mussel Mytilus galloprovincialis collected from lake Faro (Sicily, Italy). Environ. Inter. 30 (6), 805-810.

DOI: $10 / 1016 /$ j.envint.2004.01.007

Lim P.-E., Lee Ch.-K. and Din Z. (1995). Accumulation of heavy metals by cultured oysters from Merbok Estuary, Malaysia. Mar. Poll. Bull. 31 (4-12), 420-423.

DOI: $10.1016 / 0025-326 X(98) 00144-C$

Maanan M. (2008). Heavy metal concentrations in marine mollusks from the Moroccan coastal region. Environ. Poll. 153 (1), 176-183.

DOI: 10.1016/j.envpol.2007.07.024

Méndez L., Palacios E., Acosta B., Monsalvo-Spencer P. and Álvarez-Castañeda T. (2006). Heavy metals in the clam Megapitaria squalida collected from wild and phosphorite mine-impacted sites in Baja California, Mexico. Biol. Trace Element Res. 110 (3), 275-287. DOI: 10.1385/BTER:110:3:275

Miranda-Baeza M. (1994). Cultivo experimental de callo de hacha Atrina maura (Pelecypoda: Pinnidae), en la laguna de Agiabampo, Sonora. B.Sc. thesis. Centro de Estudios Superiores de Sonora, Unidad Académica Navojoa, Sonora, Mexico, 79 pp.

Morse M.P., Meyhöfer E., Otto J.J. and Kuzirian A.M. (1986). Hemocyanin respiratory pigment in bivalve mollusks. Science 231 (4743), 1302-1304.

Nauen C.E. (1983). Compilation of legal limist for hazardous substances in fish and fishery products. FAO fisheries circular 764. United Nations Food and Agriculture Organization. Rome, Italy, $102 \mathrm{pp}$.

Osuna-Martínez C.C., Páez-Osuna F. and AlonsoRodríguez R. (2010). Mercury in cultured oysters (Crassostrea gigas Thunberg 1793 and C. corteziensis Hertlein 1951) from four coastal lagoons of the SE Gulf of California, Mexico. Bull. Environ. Contam. Toxicol. 85 (3), 339-343. DOI: 10.1007/s00128-010-0071-4 
Osuna-Martínez C.C., Páez-Osuna F. and Alonso-Rodríguez R. (2011). Cadmium, copper, lead, and zinc in cultured oyeters under two contrasting climatic conditions in coastal lagoons from SE Gulf of California, Mexico. Bull. Environ. Contam. Toxicol. 87 (3), 272-275. DOI: 10.1007/s00128-011-0355-3

Páez-Osuna F., Zazueta-Padilla H.M. and Izaguirre-Fierro G. (1991). Trace metals in bivalves from Navachiste lagoon, Mexico. Mar. Poll. Bull. 22 (6), 305-307. DOI: $10.1016 / 0025-326 x(91) 90809-7$

Páez-Osuna F., Osuna-López J.I., Izaguirre-Fierro G. and Zazueta-Padilla H.M. (1993). Heavy metals in clams from a subtropical coastal lagoon associated with an agriculture drainage basin. Bull. Environ. Cont. Toxicol. 50 (6), 915-921. DOI: 10.1007/BF00209958

Páez-Osuna F., Frías-Espiricueta M. G. and Osuna-López J. I. (1995). Trace metals concentrations in relation to season and gonad maturation in the oyster Crassostrea iridescens. Mar. Environ. Res. 40 (1), 19-32. DOI: 10.1016/0141-1136(94)00004-9

Páez-Osuna F., Ruiz-Fernández A.C., Botello A.V., PonceVélez G., Osuna-López J.I., Frías-Espiricueta M.G., López-López G. and Zazueta-Padilla H.M. (2002). Concentrations of selected trace metals $(\mathrm{Cu}, \mathrm{Pb}, \mathrm{Zn})$, organochlorines (PCBs, HCB) and total PAHs in mangrove oysters from the Pacific coast of Mexico: and overview. Mar. Pollut. Bull. 44 (11), 1303-1308. DOI: S0025-326X(02)00172-8

Páez-Osuna F., Gracia A., Flores-Verdugo F., Lyle-Fritch L.P., Alonso-Rodríguez R., Roque A. and Ruiz-Fernández A.C. (2003). Shrimp aquaculture development and the environment in the Gulf of California ecoregion. Mar. Poll. Bull. 46 (7), 806-815.

DOI: $10.1016 / \mathrm{S} 0025-326 \mathrm{X}(03) 00107-3$

Páez-Osuna F. and Osuna-Martínez C.C. (2015). Bioavailability of cadmium, copper, mercury, lead, and zinc in subtropical coastal lagoons from the southeast Gulf of California using mangrove oysters (Crassostrea coretziensis and Crassostrea palmula). Arch. Environ. Contam. Toxicol. 68 (2), 305-316.

DOI: $10.1007 / \mathrm{s} 00244-014-0118-3$

Palomares-García J.M., Castañeda-Chávez M.R., LangoReynoso F. and Landeros-Sánchez C. (2009). Niveles de metales pesados en camarón café Farfantepenaeus aztecus de la Laguna de Tamiahua, Veracruz, México. Rev. Invest. Mar. 30 (1), 63-69.

Pérez A.A., Fajardo M.A., Strobl A.M., Pérez L.B., Piñeiro A. and López C.M. (2005). Contenido de plomo, cromo y cadmio en moluscos comestibles del Golfo San Jorge (Argentina). Acta Toxicol. Argentina 13 (1), 20-25.

Rodríguez-Quiroz G., García-Ulloa M., DomínguezOrozco A.L., Valenzuela-Hernández T.N., Nava-Pérez E. and Góngora-Gómez A.M. (2016). Relación del crecimiento, condición y supervivencia del ostión del Pacífico Crassostrea gigas y las variables ambientales, cultivado en suspensión en el sistema lagunar Navachiste-Macapule, Sinaloa, México. Rev. Biol. Mar. Oceanog. 51 (3), 541-551. DOI: $10.4067 / \mathrm{S} 0718-19572016000300006$

Ruelas-Inzunza J. and Páez-Osuna F. (2008). Trophic distribution of $\mathrm{Cd}, \mathrm{Pb}$, and $\mathrm{Zn}$ in a food web from Altata-Ensenada del Pabellón subtropical lagoon, SE Gulf of California. Arch. Environ. Cont. Toxicol. 54 (4), 584-596. DOI: 10.1007/s00244-007-9075-4

Ruiz C.J.A., Medina G.G., Macías J.C. and Silva M.M.S. (2005). Estadísticas climatológicas básicas del estado de Sinaloa (periodo 1961-2003). Libro técnico núm. 2. Instituto Nacional de Investigaciones Forestales, Agrícolas y Pecuarias-Centro de Investigación Regional Noroeste (INIFAP-CIRNO), Ciudad Obregón, Sonora, Mexico, $154 \mathrm{pp}$.

Ruiz-Luna A. and de la Lanza-Espino G. (1999). Sistemas rurales de producción camaronícola en Guasave, Sinaloa y norte de Nayarit (descripción física, entorno y ubicación). Centro de Investigación, Alimentación y Desarrollo (Unidad Mazatlán) y Universidad Nacional Autónoma de México, Mexico, 25 pp.

Sandrin T.R. and Maier R.M. (2002). Effect of pH on cadmium toxicity, speciation, and accumulation during naphthalene biodegradation. Environ. Toxicol. Chem. 21 (10), 2075-2079.

DOI: $10.1002 /$ etc. 5620211010

Sobrino-Figueroa A., Cáceres-Martínez M. and RosasCedillo R. (2007). Risk evaluation for mollusk consumption polluted with cadmium, chromium and lead. Hidrobiológica 17 (1), 49-58.

Soto-Jiménez M.F. and Flegal A.R. (2009). Origin of lead in the Gulf of California ecoregion using stable isotope analysis. J. Geochem. Explor. 101 (3), 209-217. DOI: $10.1016 /$ j.gexplo.2008.07.003

SSA (1993). Norma Oficial Mexicana NOM-031SSA1-1993. Bienes y servicios. Productos de la pesca. Moluscos bivalvos frescos-refrigerados y congelados. Especificaciones sanitarias. Secretaría de Salud. Diario Oficial de la Federación, 6 de marzo de 1995.

SSA (1994). Norma Oficial Mexicana NOM-109SSA1-1994. Bienes y servicios. Procedimientos para la toma, manejo y transporte de muestras de alimentos para su análisis microbiológico. Secretaría de Salud. Diario Oficial de la Federación, 26 de mayo de 1994.

Staines-Urías F., Douglas R.G. and Gorsline D.S. (2009). Oceanographic variability in the southern Gulf of California over the past 400 years: evidence from faunal and isotopic records from planktonic foraminifera. Palaeog. Palaeoclim. Palaeoecol. 284 (3-4), 337-354. DOI: 10.1016/j.palaeo.2009.10.016 
Stanković S., Jović M., Stanković A.R. and Katsikas L. (2012). Heavy metals in seafood mussels. Risk for human health. In: Environmental chemistry for a sustainable world, vol 1. Nanotechnology and health risk (Lichtfouse E., Schwarzbauer J., Robert D., Eds.). Springer, The Netherlands, 311-373 pp.

Taylor H. and Anstiss J.M. (1999). Copper and hemocyanin dynamics in aquatic invertebrates. Mar. Freshwater Res. 50 (8), 907-931. DOI: 10.1071/MF99117

Tchounwou P.B., Yedjou C.G., Patlolla A.K. and Sutton D.J. (2012). Heavy metals toxicity and the environment. Exp. Suppl. 101, 133-164.

DOI: 10.1007/978-3-7643-8340-4_6

Villanueva-Fonseca L.C. (2009). Variación genética y fenotípica en poblaciones de callo de hacha Atrina maura en la costa de Sinaloa. B.Sc. thesis. Universidad de Occidente, Unidad Guasave, Sinaloa, Mexico, 89 pp. WHO (1996). Trace elements in human nutrition and health. World Health Organization, Geneva, 178 pp.

Yap C.K., Ismail A., Tan S.G. and Rahim A. (2003). Can the shell of the green-lipped mussel Perna viridis from the west coast of Peninsular Malaysia be a potential biomonitoring material for $\mathrm{Cd}, \mathrm{Pb}$ and $\mathrm{Zn}$ ? Estuarine Coast. Shelf Sci. 57 (4), 623-630. DOI: $10.1016 / \mathrm{S} 0272-7714(02) 00401-8$

Yap C.K., Ismail A. and Tan S.G. (2009). Effect of body size on heavy metal contents and concentrations in green-lipped mussel Perna viridis (Linnaeus) from Malaysian coastal waters. Pertanika J. Sci. Technol. 17 (1), 61-68. 